\title{
ANALISIS KARAKTERISTIK DAN PERAN PENGUSAHA PEREMPUAN PADA ANGGOTA WWW.UMKMINDONESIA.ID
}

\author{
Oleh: \\ Deasy Nurmalasari \\ Program Studi Pendidikan Ekonomi \\ Fakultas Ilmu Pendidikan dan Pengetahuan Sosial \\ Universitas Indraprasta PGRI \\ Email: \\ deasynurmalasari03@gmail.com
}

\begin{abstract}
Women are a resource that has an important role in improving economic welfare. However, the contribution of women often becomes men. Nevertheless, many women entrepreneurs have succeeded in making decisions in the entrepreneurial world in the economy, especially households. Women who have relationships with highly motivated people try to independently increase productivity by participating in several pieces of training and education. The role of women in the economy by increasing creativity and innovation to solve problems and take advantage of the opportunities that exist every day. The purpose of this research is to analyze and identify the role of women in the growing economy and to form a step for women to develop self-quality or personal skills. This research takes and manages data on members of www.ukmindonesia.id who are joined until October 2019, then interviews with one of the members of the women's SME who lives in Garut. About women entrepreneurs and starting their business or venture. The results show that education, experience, and attitudes towards risk are very important to the entrepreneurial activities of women entrepreneurs.
\end{abstract}

Keyword: characteristics, motivation, the role of women 


\begin{abstract}
ABSTRAK
Perempuan merupakan sumber daya yang mempunyai peran penting untuk meningkatkan kesejahteraan ekonomi. Namun kontribusi perempuan sering kali menjadi tidak sebesar laki-laki. Meskipun demikian, banyak pengusaha perempuan yang berhasil memutuskan mengambil dunia wirausahawan dalam perekonomian khususnya rumah tangga. Perempuan mempunyai beberapa karakteristik di antaranya mempunyai motivasi tinggi, dimana untuk berusaha mandiri meningkatkan produktivitas dengan ikut bergabung dalam beberapa pelatihan dan pendidikan. Peran perempuan dalam ekonomi dengan meningkatkan kreativitas dan keinovasian untuk memecahkan permasalahan dan upaya memanfaatkan peluangpeluang yang dihadapi orang setiap hari. Tujuan dari penelitian ini adalah untuk menganalisis serta mengidentifikasi peran perempuan pengusaha terhadap perekonomian yang sedang tumbuh dan menjadikan suatu langkah bagi kaum perempuan untuk mengembangkan kualitas diri atau ketrampilan diri. Penelitian ini mengambil dan mengelola data member www.ukmindonesia.id yang tergabung sampai dengan Oktober 2019, Lalu melakukan deep interview (pada salah satu member ukm perempuan yang berdomisili di Garut. Tentang Pengusaha perempuan dan bagaimana memulai bisnis atau usahanya. Hasil penelitian menunjukan seperti pendidikan, pengalaman dan sikap terhadap pengambilan risiko sangat penting terhadap kegiatan kewirausahaan pengusaha perempuan.
\end{abstract}

Kata kunci: karakteristik, motivasi, peranan pengusaha

\title{
A. PENDAHULUAN
}

Salah satu permasalahan pembangunan yang dihadapi bangsa Indonesia adalah masalah kependudukan. Padatnya penduduk yang cenderung akan memengaruhi pendapatan perkapita dimasing-masing wilayah. Dalam hal ini kewirausahaan menjadi semakin disadari sebagai lokomotif pertumbuhan ekonomi, produktivitas, inovasi dan tersedianya lapangan pekerjaan yang secara luas diterima sebagai aspek kunci dari dinamisme ekonomi. Sejarah membuktikan bahwa kemajuan ekonomi telah secara signifikan didorong oleh orang-orang pragmatis yang memiliki sifat kewirausahawan yang inovatif, mampu memanfaatkan peluang dan bersedia mengambil risiko (Wube, 2010)

Meskipun sebelumnya wirausaha didominasi oleh laki-laki, saat ini semakin banyak wanita yang memasuki dunia usaha sebagai pilihan karir dan profesi. Orientasi kewirausahaan wanita dipengaruhi oleh tujuan, motif, identitas wanita dan karakteristik personal (Mokalu, 2016). Faktor-Faktor internal (minat, pemberdayaan, dan motivasi) memengaruhi keputusan perempuan untuk berwirausaha, terutama yang paling kuat adalah minat dan motivasi, namun pemberdayaan tidak berpengaruh secara signifikan. Diantaranya factor-faktor eksternal seperti dukungan suami, sumber daya keuangan maka hanya dukungan suami yang berpengaruh (Mokalu, 2016)

Kehadiran usaha mikro yang dikelola oleh perempuan merupakan bentuk usaha mandiri untuk tidak ketergantuang dengan laki-laki atau orang lain. Kemandirian muncul dari beberapa aspek sosial yang pada umumnya untuk 
menambah pendapatan rumah tangga dan atau pemenuhan kebutuhan rumah tangga. Oleh karena itu upaya perempuan dalam mengembangkan usahanya tidak hanya berurusan dengan masalah teknis kemampuan berbisnis, tetapi juga hubungan antara perempuan dan laki-laki.

Berbagai karakteristik yang terungkap dalam penelitian mengenai kaum perempuan bahwa pengusaha perempuan banyak peluang untuk menjadi pengusaha. Dengan semangat dan motivasi yang tinggi perempuan mampu mengembangkan keterampilannya dalam mengelola usaha serta yang bertindak dan bekerja tanpa pengarahan memliki suatu kemampuan kontrol internal yang tinggi serta kecenderungan untuk berhasil. Pengambilan risiko yang diambil kaum perempuan menunjukan adanya personal yang subjektif dalam mengelola usaha tersebut. Berbagai studi mengungkapkan bahwa terdapat serangkaian karakteristik individual yang umumnya melekat pada kaum perempuan yaitu tingkat kreativitas yang dapat mendorong terlahir gagasan dan ide-ide baru untuk bisnis atau usahanya untuk tetap berjalan.

Jumlah wanita di Indonesia sebagai pengusaha atau pemilik usaha terus bertambah mengikuti kemajuan perekonomian nasional dan perkembangan sosial yang semakin modern, yang juga didorong oleh semakin besarnya peluang bagi wanita di Tanah Air untuk mendapatkan pendidikan yang baik dan kebebasan dalam menentukan jalan hidup pribadinya, termasuk keputusannya untuk menjadi pengusaha atau memiliki usaha sendiri. Namun representasi wirausahawan wanita di Indonesia masih rendah, dan mereka berkonsentrasi terutama di usaha mikro dan kecil (Tambunan, 2012). Dengan demikian wanita perlu lebih didorong lagi untuk meningkatkan perannya, termasuk menjadi wirausahawan. Berdasarkan alasan tersebut maka perlu dilakukan penelitian untuk mengetahui faktor-faktor apa yang menyebabkan wanita memutuskan untuk memilih berwirausaha sebagai profesi mereka, terutama di daerah-daerah.

Masalah utama di dalam penelitian ini dirumuskan dengan fokus yang lebih ditekankan pada karakteristik yang memengaruhi seberapa penting peran perempuan berkontribusi pada UMKM (pengusaha perempuan).

Tujuan dari penelitian ini adalah untuk menganalisis serta mengidentitaskan peran perempuan pengusaha terhadap perekonomian yang sedang tumbuh dan menjadikan suatu langkah bagi kaum perempuan untuk mengembangkan kualitas diri atau ketrampilan diri. Penelitian ini mengambil studi kasus pada member www.ukmindonesia.id ang bergabung sampai dengan Oktober 2019.

Analisis data penelitian Berdasarkan karakteristik banyak kesenjangan gender yang dihadapi perempuan sehingga peran perempuan sering dinomor duakan masalah peekonomian. Dalam Survei di 34 provinsi di Indonesia dengan sampel $2.041 \mathrm{ibu}$ rumah tangga mengungkapkan bahwa waktu rata-rata yang dihabiskan perempuan untuk pekerjaan mengurus rumah tangga adalah 13,5 jam per hari. Angka ini lebih besar dari rata-rata perempuan di wilayah Asia Pasifik yang mencapai 7,7 jam perhari (Jurnal perempuan, 2018), Menurut BPS jumlah perempuan yang melakukan peran pengasuhan dan perawatan (mengurus rumah tangga) berjumlah $36,67 \%$ dari jumlah penduduk perempuan usia produktif $(35,34$ juta), dibandingkan dengan 3,99\% laki-laki yang mengurus rumah tangga. Kondisi ini terjadi karena kultur di masyarakat yang masih menganggap laki-laki sebagai 
pencari nafkah utama (peran produktif) dan perempuan bertanggung jawab sebagai 'ibu/istri' (peran reproduktif/domestik). Ada ekspektasi sosial terhadap perempuan untuk berhenti bekerja begitu mereka mulai memiliki anak: hampir dua pertiga $(65,33 \%)$ perempuan yang saat ini di rumah merawat keluarga mereka sebelumnya aktif bekerja tetapi berhenti, hal ini menunjukkan tantangan dalam menggabungkan tanggung jawab mengurus rumah tangga dengan pekerjaan berbayar (National et al, 2020). Dan untuk itu bagaimana cara membentuk karakteristik pengusaha perempuan serta bisnis yang terlupakan itu sehingga perempuan dapat mengembangkan diri dalam pelaku usaha sendiri serta melihat bagaimana tantangan perempuan untuk membentuk karakter sebagai wirausaha.

\section{B. KAJIAN PUSAKA}

\section{Perempuan Wirausaha}

Menurut Shane dan Venkataraman (Tambunan, 2012), berpendapat bahwa konsep dari kewirausahaan pada dasarnya adalah proses-proses penemuan, evaluasi dan eksploitasi dari peluang-peluang yang ada. Sedangkan Zimmerer (Tambunan, 2012) mengatakan bahwa kewirausahaan adalah penerapan kreativitas dan keinovasian untuk memecahkan permasalahan dan upaya memanfaatkan peluangpeluang yang dihadapi orang setiap hari. Sejalan dengan pendapat tersebut yaitu kewirausahaan lebih dari sekedar penciptaan usaha: Mencari peluang, mengambil risiko, memiliki kegigihan untuk mendorong ide menjadi realitas. Lebih jauh kewirausahaan merupakan konsep bisnis terintegrasi yang menembus individu dengan cara yang inovatif (Bastaman \& Juffiasari, 2018).

Dalam (Alibhai, 2016) menemukan bahwa kepribadian entrepreneur merupakan faktor utama, menyusul sesudahnya faktor kemampuan, faktor teknologi, dan faktor lain. Sifat kepribadian yang paling banyak dibahas oleh para ahli dalam kaitan dengan wirausaha, adalah sifat kreatif dan inovatif. Berdasarkan uraian di atas, maka studi/kajian pembentukan atau pengembangan jiwa kewirausahaan (entrepreneurship) dengan berbagai pendekatan teori perlu terus dikembangkan. Dari kajian-kajian tersebut diharapkan bisa dihasilkan suatu ide atau inovasi baru yaitu "strategi pembentukan/pengembangan jiwa wirausaha (entrepreneurship)" dalam rangka pengembangan kualitas sumber daya manusia Indonesia, khususnya peran perempuan.

\section{Peran Perempuan dalam Pengambilan Keputusan untuk Berwirausaha}

Pengambilan keputusan merupakan bagian penting dari aktifitas individual maupun bisnis. Pengambilan keputusan merupakan pilihan-pilihan dari dua atau lebih alternatif. Semua orang melakukan keputusan (Bastaman \& Juffiasari, 2018). Pengambilan keputusan selain mengarahkan terhadap pencapaian tujuan, juga setiap pengambilan keputusan melibatkan sejumlah risiko, jika keputusan yang diambil kurang tepat. Keputusan untuk memilih kewirausahaan bagi perempuan juga melibatkan sejumlah risiko, selain peluang yang dapat dimanfaatkan. Oleh karena itu terdapat beberapa faktor yang perlu dipertimbangkan dalam pengambilan keputusan. 
Dalam hal keputusan wanita untuk menjadi wirausahawan, terdapat faktor dalam diri individu sendiri (internal) dan faktor-faktor eksternal. Faktor-faktor internal antara lain: Minat, Motivasi, pemberdayaan diri. Sedangkan dalam Prosiding Seminar Nasional 4th UNS SME's Summit \& Awards 2015 "Sinergitas Pengembangan UMKM dalam Era Masyarakat Ekonomi ASEAN (MEA)" 268 faktor eksternal antara lain: Lingkungan keluarga/keturunan, dukungan suami/keluarga, sumber modal, lingkungan sosial (Sains et al., 2018).

\section{Proses dan Karakteristik Kewirausahaan}

Menurut Hisrich dalam jurnal (Mokalu, 2016), proses kewirausahaan merupakan proses untuk mengembangkan sebuah usaha baru, mungkin dalam bentuk membawa produk baru ke pasar yang ada, membawa produk yang ada ke pasar baru, dan/atau pembentukan organisasi baru. Proses ini memiliki empat tahap yang berbeda yaitu: 1) identifikasi dan evaluasi peluang, 2) pengembangan rencana bisnis, 3) penerapan sumber daya yang dibutuhkan, 4) manajemen perusahaan yang dihasilkan.

Menurut (Suryana, 2011) proses kewirausahaan diawali dengan adanya tantangan. Dari tantangan tersebut muncul gagasan (ide), kemauan, dan dorongan untuk berinisiatif, yaitu berpikir kreatif dan bertindak inovatif. Semua tantangan pasti memiliki risiko, yaitu kemungkinan berhasil atau tidak berhasil (gagal).ide kreatif dan inovatif wirausaha tidak sedikit yang diawali dengan proses imitasi dan duplikasi, kemudian berkembang menjadi proses pengembangan dan berujung pada proses penciptaan sesuatu yang baru dan berbeda (inovasi). Berikut merupakan tantangan-tantangan yang akan dihadapi oleh pengusaha perempuan:

\section{Pendidikan dan Pelatihan}

Apabila kemampuan teknis kaum perempuan meningkat, maka bisnis mereka juga berkembang. Ada empat asosiasi perempuan pengusaha cocok sekali untuk memenuhi kebutuhan pelatihan para anggotanya, dengan lebih dahulu melakukan survei terhadap mereka agar dapat merancang program pelatihan yang tepat.

\section{Infrastruktur Hukum}

Merancang teknologi bisnis agar dapat menciptakan sistem yang paling murah, mungkin dalam bentuk kolaborasi, yang dapat menghubungkan perempuan pengusaha dengan dunia adalah sangat penting dalam dunia bisnis yang bersaing dalam pasar global.

\section{Pengakuan Atas Kepemilikan Usaha}

Dalam masyarakat patriakis tradisional, perempuan pengusaha seringkali tidak dapat diterima. Kampanye melalui media dapat membantu integrasi perempuan pengusaha ke dalam masyarakatnya. Manakala pandangan positif tentang merka dan tentang kewirausahan pada umumnya semakin dapat diterima, maka fenomena pengusaha yang sedang merebak ini akan menumbuhkan kemungkinan-kemungkinan baru bagi stabilitas ekonomi serta perkembangan bisnis dunia. 


\section{Karakteristik Kewirausahaan}

Seperti diungkapkan Alma dalam jurnal (Bastaman \& Juffiasari, 2018), perempuan pengusaha lebih banyak memiliki sifat:

1) toleransi dan fleksibel, lebih banyak memaklumi masalah karyawannya dan mau bertenggang rasa/tolerance.

2) realistik dan kreatif, lebih realistik terhadap target dan cendrung kreatif menyesuaikan

3) antusias dan energik, bersemangat dan penuh energi untuk berusaha

4) mampu berhubungan dengan lingkungan masyarakat, karena sifat fleksibelnya

5) memiliki medium level of self confidence, hal ini kadang menjadikan perempuan tidak

6) begitu total dalam bisnis, karena banyaknya urusan yang diselesaikan/ ditangani perempuan

7) pengusaha disamping urusan domestiknya.

Berdasarkan ciri-ciri wirausahawan di atas dapat diidentifikasi sikap seorang wirausahawan yang dapat dilihat dari kegiatannya sehari-hari:

1) disiplin yang tinggi terhadap tugas dan pekerjaannya

2) komitmen/kesepakatan yang jelas, terarah, dan berorientasi pada kemajuan,

3) memiliki kejujuran sebagai landasan moral seorang wirausahawan,

4) memiliki daya kreativitas yang tinggi dan inovatif,

5) kemandirian tanpa ketergantungan kepada pihak lain dalam mengambil keputusan atau bertindak, realistik sebagai landasan berpikir rasional dalam setiap pengambilan keputusan maupun tindakan atau perbuatannya.

\section{Kriteria UMKM Berdasarkan Asset atau Omzet}

Berdasarkan Undang-Undang yang mengatur UMKM adalah (UndangUndang No 20 Tahun 2008 Tentang Usaha Mikro, Kecil, Dan Menengah, 2008) ada 3 kategori utama UMKM berdasarkan jumlah omzet dan asset yang mereka miliki, yaitu:

1. Usaha Mikro: memiliki kekayaan bersih paling banyak Rp 50.000.000 (lima puluh juta rupiah), tidak termasuk tanah dan bangunan tempat usaha; atau memiliki hasil penjualan tahunan paling banyak Rp 300.000.000 (tiga ratus juta rupiah)

2. Usaha kecil: Memiliki kekayaan bersih lebih dari Rp 50.000.000 (lima puluh juta rupiah) sampai dengan Rp 500.000.000 (lima ratus juta rupiah) tidak termasuk tanah dan bangunan tempat usaha; atau memiliki hasil penjualan tahunan lebih dari Rp 300.000.000 (tiga ratus juta rupiah) sampai dengan paling banyak Rp 2.500.000.000 (dua milyar lima ratus juta rupiah).

3. Usaha menengah: memiliki kekayaan bersih lebih dari Rp 500.000.000 (lima ratus juta rupiah) sampai dengan $\mathrm{Rp}$ 10.000.000.000 (sepuluh miliar rupiah) tidak termasuk tanah dan bangunan tempat usaha; atau memiliki hasil penjualan tahunan lebih dari Rp 2.500.000.000 (dua milyar lima ratus juta rupiah) sampai dengan Rp 10.000.000.000 (sepuluh miliar rupiah). 


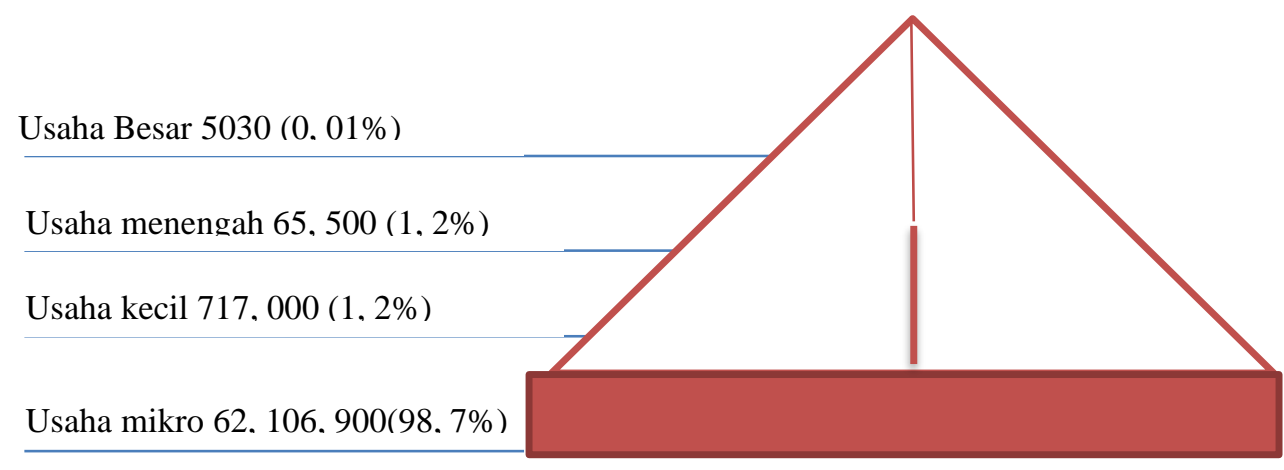

Sumber: (Women Entreprenuers in Indonesia, 2016)7.diolah penulis

Gambar 1.

Rentang Usia Women Entrepreneurs

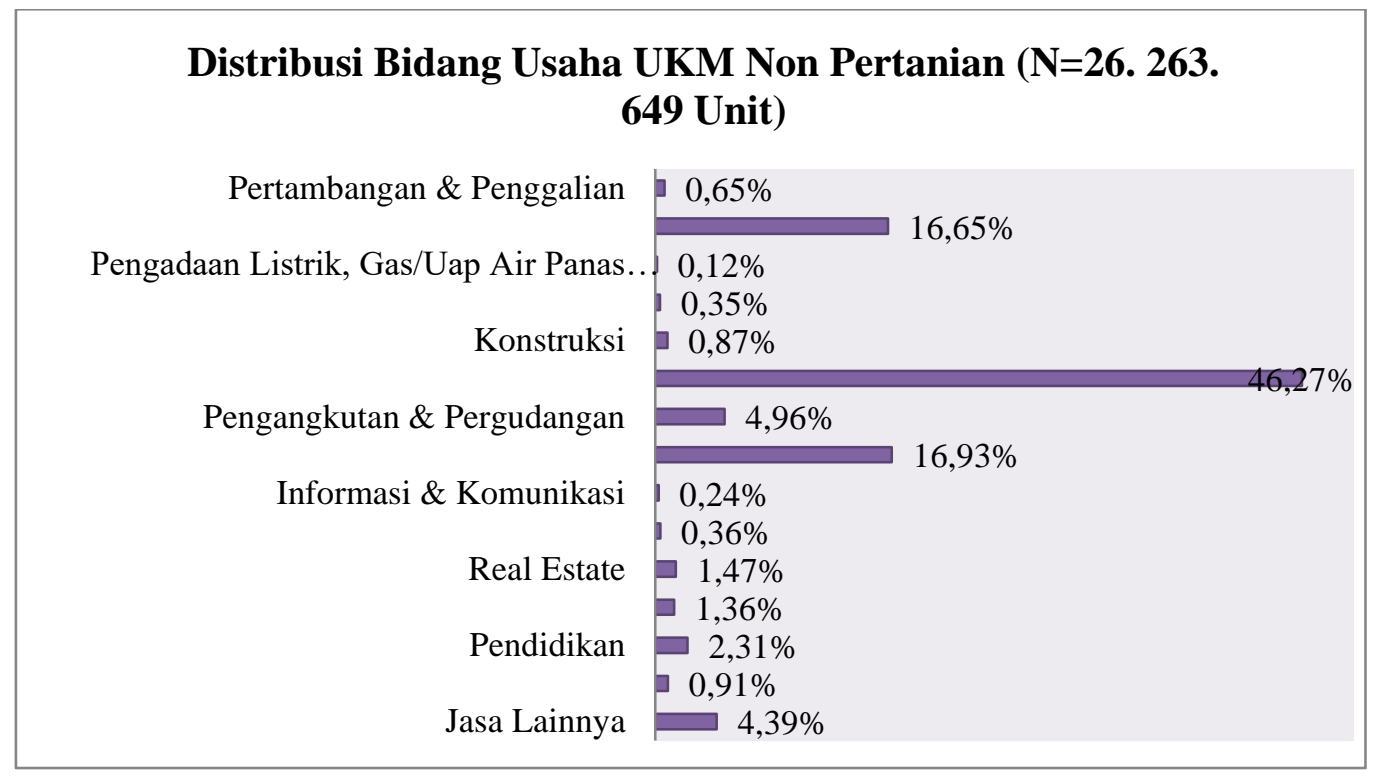

Sumber : Sensus Ekonomi 2016, (Statistik, n. d. ), diolah penulis

\section{Gambar 2.}

\section{Grafik Distribusi Bidang Usaha UKM Non Pertanian}

Bidang usaha ukm dari sektor perdagangan besar dan eceran yang merupakan persentasi tertinggi sebesar 46, 27\%. Yakni ada 5 bidang di dalamnya seperti:

1. Makanan dan Minuman (44.9\%)

2. Kerajinan Kayu dan Anyaman (19.9\%)

3. Tekstik dan Pakain Jadi (14. 4\%)

4. Barang galian bukan logam seperti tepung, mika dll (6.9\%)

5. Furniture (3. 5\%)

Dari lima macam bidang bila diperhatikan keterlibatan perempuan dalam kegiatan ekonomi seringkali dianggap "tidak bekerja." Hal itu terjadi dalam UU 16 Tahun 2019 atas Perubahan UU No. 1 Tahun 1974 Tentang Perkawinan, menempatkan perempuan sebagai "pencari nafkah tambahan", namun memang 
kenyataannya peranan perempuan di pedesaan dalam pengelolaan sumber daya ekonomi sebagian besar merupakan perpanjangan kerja-kerja domestik yang dianggap sebagai "kerja non produktif."

Seperti halnya di negara-negara berkembang lainnya, perkembangan womenpreneurs Indonesia sangat berpotensi sebagai motor utama proses pemberdayaan wanita dan transformasi social, yang pada akhirnya berdampak positif terhadap tingkat perekonomian negara. Apalagi Indonesia ikut meratifikasi program PBB dalam mencapai Tujuan-tujuan Pembangunan Milenium (Millenium Development Goals/MDGs), yang dua di antaranya adalah pemberdayaan wanita dan mengurangi kemiskinan pada tahun 2015.

\section{METODE PENELITIAN}

Tulisan ini mengacu dari berbagai referensi dan sinkronisasi data dari www.ukmindonesia.id dan banyak perempuan yang ikut begabung menjadi member di ukmindonesia dari berbagai macam bidang. Rata-rata motivasi mereka ikut bergabung member adalah ingin mendapat pelatihan dan pemberdayaan untuk mereka berkembang dalam menjalankan suatu usaha. Dalam (Sugiyono, 2016), Pendekatan deskripsi kualitatif dipakai sebagai acuan dengan didahului oleh observasi, serta dalam mengumpulkan data menggunakan wawancara mendalam dengan salah satu member www.ukmindonesia.id. Di samping itu data tambahan lainnya adalah data kuantitatif yang diolah sebagai potret karakteristik pengusaha perempuan yang menjadi member www.ukmindonesia.id. Data yang digunakan data primer (data yang diambil dilapangan) dan data sekunder berupa dokumentasi, foto, jurnal ilmiah, data terlampir.

Menurut (Santana k, 2010) Dalam penelitian kualitatif, yang menjadi instrumen atau alat penelitian adalah peneliti itu sendiri. Oleh karena ini peneliti sebagai instrumen juga harus "divalidasi" seberapa jauh peneliti kualitatif siap melakukan penelitian yang selanjutnya terjun ke lapangan.

\section{HASIL DAN PEMBAHASAN}

\section{Profil Member UKM Indonesia}

Pengolahan data member UKM Indonesia diambil dari member yang sudah bergabung per Oktober 2019 yaitu sebanyak 1050 member.

Tabel 1.

Kategori Berdasarkan Wilayah Dan Persentase Jenis Kelamin

\begin{tabular}{lcccccc}
\hline \multirow{2}{*}{\multicolumn{1}{c}{ CATEGORY }} & \multicolumn{5}{c}{ GENDER } & \multicolumn{2}{c}{ Total } & $\%$ \\
\hline Jawa Barat & L & \% & P & $\%$ & & \\
Jawa tengah & 765 & $30 \%$ & 156 & $31 \%$ & 351 & $31 \%$ \\
DI Yogyakarta & 50 & $8 \%$ & 58 & $12 \%$ & 108 & $10 \%$ \\
DKI Jakarta & 59 & $9 \%$ & 48 & $10 \%$ & 107 & $10 \%$ \\
Jawa timur & 55 & $8 \%$ & 49 & $10 \%$ & 104 & $9 \%$ \\
Banten & 40 & $6 \%$ & 39 & $8 \%$ & 79 & $7 \%$ \\
Sumatera Utara & 25 & $4 \%$ & 14 & $3 \%$ & 39 & $4 \%$ \\
\hline
\end{tabular}




\begin{tabular}{lcccccc}
\hline Sulawesi Selatan & 19 & $3 \%$ & 18 & $4 \%$ & 37 & $4 \%$ \\
Bali & 10 & $2 \%$ & 17 & $3 \%$ & 27 & $3 \%$ \\
Aceh & 21 & $3 \%$ & 3 & $1 \%$ & 24 & $2 \%$ \\
Lainnya & 101 & $16 \%$ & 52 & $10 \%$ & 153 & $13 \%$ \\
\hline
\end{tabular}

Sumber: Data Premier yang diolah penulis (Www.ukmindonesia.id, 2019)

Tabel 2.

Kategori UMKM Berdasarkan Tingkatannya Omset Usaha

\begin{tabular}{|c|c|c|c|c|c|c|}
\hline \multirow{2}{*}{ CATEGORY } & \multicolumn{4}{|c|}{ GENDER } & \multirow{2}{*}{ Total } & \multirow{2}{*}{$\%$} \\
\hline & $\mathbf{L}$ & $\%$ & $\mathbf{P}$ & $\%$ & & \\
\hline Micro & 518 & $80 \%$ & 369 & $74 \%$ & 887 & $77 \%$ \\
\hline Small & 119 & $18 \%$ & 126 & $25 \%$ & 245 & $22 \%$ \\
\hline Medium & 14 & $2 \%$ & 4 & $1 \%$ & 18 & $2 \%$ \\
\hline
\end{tabular}

Sumber: Data Premier yang diolah penulis (Www.ukmindonesia.id, 2019)

Tabel 3.

Kategori berdasarkan Usia

\begin{tabular}{cccccccc}
\hline \multirow{2}{*}{ CATEGORY } & \multicolumn{6}{c}{ GENDER } & \multicolumn{2}{c}{ Total } & $\%$ \\
\hline Usia & $35-39$ & 120 & $18 \%$ & 97 & $19 \%$ & 217 & $19 \%$ \\
& $40-44$ & 78 & $12 \%$ & 85 & $17 \%$ & 163 & $15 \%$ \\
& $30-34$ & 125 & $19 \%$ & 77 & $15 \%$ & 202 & $17 \%$ \\
& $25-29$ & 158 & $24 \%$ & 76 & $15 \%$ & 234 & $20 \%$ \\
$45-49$ & 61 & $9 \%$ & 75 & $15 \%$ & 136 & $12 \%$ \\
$20-24$ & 56 & $9 \%$ & 34 & $7 \%$ & 90 & $8 \%$ \\
$50-54$ & 31 & $5 \%$ & 33 & $7 \%$ & 64 & $6 \%$ \\
$55-59$ & 12 & $2 \%$ & 11 & $2 \%$ & 23 & $2 \%$ \\
& $>60$ & 5 & $1 \%$ & 9 & $2 \%$ & 14 & $2 \%$ \\
$15-19$ & 5 & $1 \%$ & 2 & $1 \%$ & 7 & $1 \%$ \\
& 651 & 1 & 499 & $100 \%$ & 1150 & $100 \%$ \\
\hline
\end{tabular}

Sumber: Data Premier yang diolah penulis (Www.ukmindonesia.id, 2019)

Tabel 4.

Kategori berdasarkan Badan Usaha

\begin{tabular}{cccccccc}
\hline \multirow{2}{*}{ CATEGORY } & \multicolumn{5}{c}{ GENDER } & Total & \multirow{2}{*}{$\%$} \\
\cline { 3 - 8 } & Individual & 120 & $18 \%$ & 97 & $19 \%$ & 217 & $19 \%$ \\
\multirow{2}{*}{ Business entity } & $\mathrm{CV}$ & 78 & $12 \%$ & 85 & $17 \%$ & 163 & $15 \%$ \\
\hline
\end{tabular}




\begin{tabular}{lcccccc}
\hline PT & 125 & $19 \%$ & 77 & $15 \%$ & 202 & $17 \%$ \\
Grup bisnis & 14 & $2 \%$ & 8 & $2 \%$ & 22 & $2 \%$ \\
Coorperation & 10 & $2 \%$ & 2 & $0 \%$ & 12 & $1 \%$ \\
Firma & 1 & $0 \%$ & 0 & $0 \%$ & 1 & $0 \%$ \\
\hline Sumber: Data Premier yang diolah penulis $(W w w . u k m i n d o n e s i a . i d, 2019)$
\end{tabular}

Tabel 5.

Kategori Berdasarkan Ketergabungan Bersama Komunitas

\begin{tabular}{ccccccc}
\hline \multicolumn{1}{c}{ CATEGORY } & \multicolumn{6}{c}{ GENDER } \\
& $\mathbf{L}$ & $\boldsymbol{\%}$ & $\mathbf{P}$ & $\mathbf{\%}$ & Total & $\boldsymbol{\%}$ \\
\hline Tidak Memiliki Komunitas & 556 & $85 \%$ & 379 & $76 \%$ & 935 & $81 \%$ \\
Memiliki Komunitas & 95 & $15 \%$ & 120 & $24 \%$ & 215 & $19 \%$ \\
Total & 651 & $100 \%$ & 499 & $100 \%$ & 1150 & $100 \%$ \\
\hline Sumber: Data Premier yang diolah penulis $($ Www.ukmindonesia.id, 2019)
\end{tabular}

Dari data tersebut member UKM Indonesia kebanyakan berasal dari Jawa yaitu sebesar 76\%. Dan rentang usia 25-49 tahun dalam persentase tertinggi sebanyak $78 \%$ untuk memulai atau sedang merintis usaha. Dan $98 \%$ pelaku usaha masih kategori golongan mikro serta hanya $17 \%$ yang berbadan hukum. Fakta menarik dari profil member antara laki-laki dan perempuan www.ukmindonesia.id adalah: Rentang usia member perempuan terbanyak di 35-45 (35\%), sementara laki-laki diusia 25-35 (43\%) yang dimana perempuan biasanya setelah menikah, hamil dan melahirkan anak. Bidang UMKM non pertanian : Pedagang, industri makanan, dan penyajian makanan. Bidang UMKM perempuan: tekstil, pakaian jadi, dan aksesoris kerajinan tangan. Ada pola bahwa perempuan "lebih cepat puas", karena proporsi perempuan di skala usaha menengah, yang punya NPWP, atau yang berbadan usaha formal, lebih sedikit dari member laki-laki. Wirausaha perempuan cenderung memfasilitasi lebih banyak tenaga kerja perempuan pula. Lebih banyak member perempuan yang tergabung dalam komunitasnya.

\section{Profil Member UKM Melek Digital}

Tabel 6.

Kategori Kepemilikan Media Sosial

\begin{tabular}{|c|c|c|c|c|c|c|c|}
\hline \multirow{2}{*}{\multicolumn{2}{|c|}{ CATEGORY }} & \multicolumn{4}{|c|}{ Gender } & \multirow{3}{*}{$\begin{array}{r}\text { Total } \\
639\end{array}$} & \multirow{3}{*}{$\begin{array}{c}\% \\
56 \%\end{array}$} \\
\hline & & \multirow{2}{*}{$\frac{M}{347}$} & \multirow{2}{*}{$\begin{array}{c}\% \\
53 \%\end{array}$} & \multirow{2}{*}{$\frac{\boldsymbol{F}}{292}$} & \multirow{2}{*}{$\frac{\%}{59 \%}$} & & \\
\hline Social Media & Memiliki & & & & & & \\
\hline & Tidak Memiliki & 304 & $47 \%$ & 207 & $41 \%$ & 511 & $44 \%$ \\
\hline Total & & 651 & $100 \%$ & 499 & $100 \%$ & 1150 & $100 \%$ \\
\hline
\end{tabular}

Tabel 7.

Kategori Kepemilikan Website

\begin{tabular}{llll}
\hline CATEGORY & Gender & Total & $\%$ \\
\hline
\end{tabular}




\begin{tabular}{llrrrrrr}
\hline & & $\boldsymbol{M}$ & \multicolumn{1}{c}{$\%$} & $\boldsymbol{F}$ & \multicolumn{1}{c}{$\%$} & & \\
\hline Website & Memiliki & 505 & $78 \%$ & 393 & $79 \%$ & 898 & $78 \%$ \\
& Tidak memiliki & 146 & $22 \%$ & 106 & $21 \%$ & 252 & $22 \%$ \\
Total & & 651 & $100 \%$ & 499 & $100 \%$ & 1150 & $100 \%$ \\
\hline
\end{tabular}

Sumber :Data Primer diolah penulis (Www.ukmindonesia.id, 2019)

Tabel 8.

Kategori Kepemilikan Marketplace

\begin{tabular}{|c|c|c|c|c|c|c|c|}
\hline \multirow{2}{*}{\multicolumn{2}{|c|}{ CATEGORY }} & \multicolumn{4}{|c|}{ Gender } & \multirow{3}{*}{$\begin{array}{r}\text { Total } \\
639\end{array}$} & \multirow{3}{*}{$\begin{array}{c}\% \\
81 \%\end{array}$} \\
\hline & & \multirow{2}{*}{$\frac{\boldsymbol{M}}{542}$} & \multirow{2}{*}{$\frac{\%}{83 \%}$} & \multirow{2}{*}{$\begin{array}{c}\boldsymbol{F} \\
393\end{array}$} & \multirow{2}{*}{$\frac{\%}{79 \%}$} & & \\
\hline Marketplace & Memiliki & & & & & & \\
\hline & Tidak memiliki & 109 & $17 \%$ & 106 & $21 \%$ & 511 & $19 \%$ \\
\hline Total & & 651 & $100 \%$ & 499 & $100 \%$ & 1150 & $100 \%$ \\
\hline
\end{tabular}

Sumber :Data Primer diolah penulis (Www.ukmindonesia.id, 2019)

Dari keseluruhan hanya 19\% member ukm yang menggunakan platform ecommerce, $22 \%$ memiliki website sendiri dan hanya $44 \%$ Ukm yang menggunakan media sosial.

\section{Profil dan Respon Informan}

Informan dalam penelitian ini ada salah satu perempuan yang berdomisili di Garut tepatnya di kota Cibatu yang sudah bergabung menjadi member www.ukmindonesia.id. Profil pendidikan informan S1 Lulusan Ekonomi di salah satu fakultas. Informan pernah bekerja di BUMN sampai usia 28 tahun, dan memiliki anak pada usia 30 tahun. Berikut merupakan pertanyaan kepada informan:

1. Pertanyaan mengenai demografis: Daerah asal, usia, kapan terakhir bekerja, status perkwaninan?

2. Bagaimana memutuskan untuk membuat usaha dan mengapa anda memilih usaha ini?

3. Mengapa tertarik menjadi wirausaha/pengusaha perempuan?

4. Darimana mendapat modal usaha? Apakah sebelumnya ibu mempunyai modal untuk membuat usaha ini ?

5. Apa saja yang menjadi hambatan sebagai pengusaha ?

6. Bagaimana kiat-kiat bisa bertahan menjalankan usaha ini dimasa pandemic?

7. Apa kendala yang paling utama dalam melakukan usaha ini?

8. Bagaimana cara anda agar terus dapat orderan?

9. Bagaimana peluang usaha ini dimasa depan? Apakah anda sudah memikirkan

10. Bagaimana tetap eksis dan konsisten dengan usaha anda?

Usia Ibu LN berada pada rentang 30 sampai 45 tahun usia ini merupakan usia produktif bagi perempuan. Setelah Ibu LN menikah dan melahirkan anak pertamanya suami ibu LN tidak lagi mengizinkan ibu LN untuk bekerja. Akhirnya ibu LN memutuskan untuk berhenti bekerja saat itu dan memilih untuk menjadi wirausahawan. Menurut suami ibu LN menjadi seorang pengusaha perempuan 
merupakan pilihan yang tepat disamping mengurus rumah tangga ibu LN serta menjadi produktif.

Hal ini sudah terbukti oleh Ibu LN yang sudah menekuni usahanya selama empat tahun. Sejak kecil ibu LN sudah memiliki bakat menggambar dan sekarang terus dikembangkan sampai jadi sebuah usaha konveksi aneka jaket dan tas kulit. Selain usaha konveksi ibu LN juga memberdayakan ibu-ibu disekitar rumahnya untuk memproduksi kripik singkong bahkan dalam kegiatan konveksi lainnya.

Pengusaha mikro, kecil dan menengah merupakan fondasi bagi perkembangan ekonomi di Indonesia. Pengusaha mikro, kecil dan menengah menjadi motor inovasi dan perkembangan nasional karena dapat membuka lapangan pekerjaan, menyediakan barang dan jasa nasional serta berkontribusi dalam upaya mengurangi pengangguran, sehingga turut membantu memberantas kemiskinan. Sebagian besar wanita wirausahawan justru berkecimpung di Usaha Mikro dan Kecil (Mokalu, 2016). Sehingga Wanita pengusaha mempunyai peranan yang sangat penting dalam pertumbuhan ekonomi di Indonesia. Menurut data Kementerian Koperasi dan UKM, dari total kegiatan usaha mikro, kecil dan menengah (UMKM) di Indonesia, 60\% dikelola oleh kaum pengusaha wanita. Berdasarkan data diatas, dapat dikatakan bahwa perempuan pengusaha mempunyai peranan yang sangat penting dalam ekonomi nasional.

Motivasi untuk menjadi wirausaha merupakan jawaban dari sebagian besar informan untuk memutuskan menjadi wirausaha. Motivasi merupakan salah satu faktor yang menjadi pendorong dalam pengambilan keputusan menjadi wirausaha. Motivasi dianggap sebagai suatu komponen kewirausahaan yang penting. Menurut Vijaya (Bastaman \& Juffiasari, 2018) ditemukan bahwa motivasi dan variabel demografis memberikan kontribusi yang paling signifikan terhadap intensi wanita untuk berwirausaha.

Hambatan-hambatan yang dialami dalam memulai usaha yaitu pendidikan dan pelatihan. Dimana kalua seorang wirausaha harus melek digital karena dulu itu beliau dengan modal nekat dengan memposting beberapa barang milik orang lain sebelum memproduksi sendiri. Selanjutnya kiat-kiatnya untuk tetap bertahan di masa pandemic belum lama ini Ibu LN mencoba bergabung dengan aggregator di Jakarta dengan pengadaan masker dan mencoba sedikit dengan menyanggupi kapasitas yang ada. Ibu LN sudah membuktikan bahwa beliau itu mampu dan saya akan menciptakan integritas yang tinggi serta kepercayaan rekan bisnis. Dengan berintegritas dan amanah akan menimbulkan suatu hubungan baik dengan kepercayaan itu yang ibu LN sampaikan untuk tetap dapat orderan.

Kewirausahaan untuk masa depan, Kita hidup dalam suatu masyarakat yang semakin menuntut kita untuk berperilaku wirausaha pada semua tataran. Kebanyakan pernyataan politis dan kebijakan yang menyangkut arti penting kewirausahaan dan pendidikan wirausaha dibungkus dalam retorika daya saing. Kita perlu mengeksplorasi lebih jauh mengapa hal ini terjadi. Mungkin hal ini akan memberikan petunjuk kepada kita tentang apa yang seharusnya diajarkan dan bagaimana. Beliau akan membuat konveksi untuk baju anak perempuan yang mengikuti model korea atau merek luar.

Temuan penelitian sebelumnya menunjukkan atribut individual, seperti pendidikan, pengalaman dan sikap terhadap pengambilan risiko sangat penting 
terhadap kegiatan kewirausahaan pengusaha wanita. Demikian halnya dengan faktor-faktor lingkungan, seperti ketersediaan fasilitas kredit sangat penting untuk kegiatan kewirausahaan. Namun, literatur atas temuan hasil studi menunjukkan dukungan yang kuat bahwa faktor-faktor lingkungan bisnis seperti adanya akses terhadap kredit menghasilkan lebih banyak pengaruh terhadap kegiatan kewirausahaan wanita dibandingkan atribut individual (Jurnal perempuan, 2018).

Terlepas dari penjelasan tersebut di atas temuan lain menunjukkan bahwa latar belakang keluarga memiliki pengaruh yang kecil terhadap kesuksesan wirausahawan wanita (Perempuan, 2019). Temuan penelitian ini menunjukkan bahwa peran perempuan dalam ekonomi merupakan faktor penting yang memotivasi perempuan untuk memulai mendirikan usaha mereka.

\section{E. SIMPULAN}

Pengusaha mikro, kecil dan menengah menjadi motor inovasi dan perkembangan nasional karena dapat membuka lapangan pekerjaan, menyediakan barang dan jasa nasional serta berkontribusi dalam upaya mengurangi pengangguran, sehingga turut membantu memberantas kemiskinan. Sebagian besar wanita wirausahawan justru berkecimpung di usaha Mikro dan Kecil (Mokalu, 2016). Untuk itu, perempuan sangat berperan dalam upaya mengagulangi/ mengambil keputusan untuk menjadi wirausaha terdapat banyak faktor internal dan didominasi dengan faktor eksternal seperti keluarga. Dalam sisi peran maka perempuan yang sudah menikah memiliki daya Tarik untuk berprodutif melalui wirausaha yang bisa menjadi dua peran yaitu mengurus rumah tangga sekaligus menjadi pengusaha dan meciptakan lapangan pekerjaan bagi perempuanperempuan lainnya. Faktor-Faktor internal (minat, pemberdayaan, dan motivasi) memengaruhi keputusan perempuan untuk berwirausaha, terutama yang paling kuat adalah minat dan motivasi, namun pemberdayaan tidak berpengaruh secara signifikan.

Secara umum, regulasi dan kebijakan di Indonesia tidak membatasi akses perempuan terhadap berbagai kesempatan-kesempatan untuk menjadi perempuan produktif. Namun, hal hal yang menjadi tantangan bagi perempuan untuk berpartisipasi produktif (termasuk menjadi wirausaha) ditengarai lebih disebabkan oleh faktor budaya. Contohnya Perempuan diposisikan untuk bertanggungjawab penuh untuk urusan domestik rumah tangga. Sehingga, waktu yang tersisa untuk produktif di hal lain menjadi lebih terbatas. Berbeda jika suami dan istri mau berbagi tugas dan tanggung jawab dalam urusan domestik rumah tangga. Di Indonesia lebih umum perempuan bertanggungjawab penuh urusan rumah tangga. Hal ini terlihat dari tingkat partisipasi kerja jauh lebih rendah dari laki laki. Terlihat juga dalam hasil penelitian ini bahwa Rentang usia pengusaha perempuan terbanyak di 35-45 tahun. Hal ini disebabkan kebanyakan pengusaha perempuan mulai tenang memulai usaha setelah anaknya cukup besar. Karakteristik perempuan yang cepat memahami kondisi setempat dan berusaha untuk menciptakan peluangpeluang yang ada, bermotivasi tinggi serta senang melakukan kegiatan yang dapat bermanfaat untuk sesama perempuan lain menjadikan peran pengusaha perempuan dalam perekonomian menjadi faktor penting yang memotivasi perempuan untuk memulai mendirikan usaha mereka. 


\section{DAFTAR PUSTAKA}

Alibhai, A. S. (2016). Women entrepreneurs in Indonesia : a pathway to increasing shared prosperity. https://documents. world bank. org/curated/en/738881467782741648/Women-entrepreneurs-in-Indonesia-a pathway-to-increasing-shared-prosperity. (n. d. ).

Bastaman, A. , \& Juffiasari, R. (2018). Faktor-Faktor Yang Memengaruhi Pengambilan Keputusan Bagi Wanita Untuk Berwirausaha (Studi Kasus Anggota Ikatan Wanita Pengusaha Indonesia DKI Jakarta). Universitas Trilogi, Jakarta, 2013, 265-277. https://psp-kumkm. lppm. uns. ac.id/wpcontent/uploads/sites/21/2016/01/aam-bastaman-prosiding-sme-scombinedpdf_1.pdf

Jurnal perempuan. (2018). Perempuan dan Ekonomi Perawatan. 23, 249-258. www. indonesianfeminimistjournal. org

Mokalu, B. J. (2016). Perempuan Berwirausaha Mengentas Ekonomi Keluarga. Jurnal LPPM Bidang EkoSosBudKum, 3(2), 72-88.

National, S. , Inklusif, K. , Women, N. , \& Strategy, F. I. (2020). Strategi National Keuangan Inklusif Perempuan 0 National Women's Financial Inclusion Strategy. 1-55. https://snki. go.id/

Perempuan, D. A. N. (2019). ASURANSI MIKRO INDONESIA ' FINANCIAL INCLUSION INSIGHT', SNKI 2019. https://snki. go.id/

Sains, F. , Polisi, P. , Cawangan, U. , \& Sembilan, N. (2018). Prestasi Pengusaha Wanita: Hasil Pembentukan Faktor Modal Insan dan Daya Saing Abstrak Performance of Women Entrepreneurs : A Result on Formation of Human Capital and Emulous Factors Abstract Pengenalan. 3(3), 173-188.

Santana k, S. (2010). Menulis ilmiah, Metodologi penelitian kualitatif. Yayasan Obor Indonesia.

Statistik, B. P. (n. d. ). Sensus ekonomi. http://se2016. bps. go.id

Sugiyono. (2016). Metode Penelitian Kuantitatif, Kualitatif, dan R\&D. Alfabeta.

Suryana. (2011). Kewirausahawan. Salemba empat.

Tambunan, tulus. (2012). Wanita pengusaha di UMKM di Indonesia: Motivasi dan Kendala. Center for Industry, SME and Business Competition Studies, Trisakti University. Published by LPFE Trisakti University 2012.

Ui, L. F. E. B. (2019). UMKM dan Fenomena Missing Middle. https://ukmcenterfeb. ui. ac.id/

www.ukmindonesia.id. (2019). https://www.ukmindonesia.id

Undang-Undang No 20 Tahun 2008 Tentang Usaha Mikro, Kecil, dan Menengah. (2008). https://www. bi. go.id/id/tentang-bi/uubi/Documents/UU20Tahun2008UMKM. pdf 
women entreprenuers in Indonesia. (2016). http://www. depkop. go.id/data-umkm

Wube, M. C. (2010). Factors Affecting Performance of Women Entrepreneurs in Micro and Small Entreprises. https://unevoc. unesco. org/e-forum/thesis final. pdf 